\title{
Effectiveness of Information, Education, Communication Package on Knowledge Regarding Prevention of Road Traffic Accidents among High School Students in a Selected School at Puducherry
}

\author{
Geetha C
}

\begin{abstract}
Introduction: School students are active youngsters who receive decreasing amounts of supervision from parents and other adults. They are more prone to accidents. ${ }^{1}$ The accident is unintended injury, death, or property damage occurring in a sequence of events. Accidents do not just happen; they are caused through thoughtlessness, carelessness, negligence, and a momentary lack of concentration. ${ }^{2}$ They have to be taught, trained, and sensitized to traffic rules and accidents.

Objectives: (i) To assess the knowledge regarding prevention of road traffic accidents (RTAs) among high school students in a selected school at Puducherry; (ii) to assess the effectiveness of information, education, communication (IEC) package on knowledge regarding prevention of RTAs among high school students in a selected school at Puducherry; and (iii) to find out the association between knowledge scores with selected demographic variables.

Methodology: Preexperimental one-group pretest-posttest design was adapted for this study. The simple random sampling technique was used to select the sample of 50 high school students. They were assessed by using IEC package on prevention of RTA. The data were analyzed in terms of both descriptive statistics and inferential statistics.

Major findings: The study finding revealed that out of 50 high school students, 36 (72\%) of them had adequate knowledge, 14 (28\%) of them had moderate knowledge, and $0(0 \%)$ of them had inadequate knowledge regarding prevention of RTA. The analysis shows that the mode of transport is nearly associated with knowledge level, and the $p$-value is 0.975 among the high school students.

Conclusion: The study results proved that IEC package on knowledge regarding prevention of RTA among high school students was highly effective. They will enable them to improve the awareness regarding the traffic rules, and it helps to reduce the RTA among school students. Keywords: High school students, Knowledge, Prevention, Road traffic accident.

Pondicherry Journal of Nursing (2021): 10.5005/jp-journals-10084-13112
\end{abstract}

\section{INTRODUCTION}

Children are the inheritance of God. They are like clay in potter's hand. They are more likely to be involved in an accident. ${ }^{1}$ Unintentional injury, death, or property damage occurs as a result of a chain of circumstances. They are caused by a lack of thought, carelessness, negligence, and a temporary lapse in concentration. ${ }^{2}$ Children under the age of 12 are more likely to be involved in bicycle accidents. It has been found that kids aged 12-15 who are involved in traffic accidents get fractures, sprains, open wounds, and other injuries for which they must seek medical attention. In 2015, over 137,000 persons were killed in road accidents, which is more than the total number of people murdered in all of our wars combined. Every day, 16 children killed on Indian road. ${ }^{3-6}$

In India, one person dies every 4 minutes as a result of a road accident. Every day, 1,214 road accidents occur in India. ${ }^{7,8}$ Twowheelers account for $25 \%$ of all accidents on the road. ${ }^{9,10}$ Every day, 20 children under the age of 14 die in road accidents in the United States. Bicycles accounted for the biggest percentage of vehicles involved in RTAs (19.4\%), followed by trucks (16.8\%) and buses (14.9\%) among motorized vehicles. The figures from Chennai were
Department of Child Health Nursing, Kasturba Gandhi Nursing College, Sri Balaji Vidyapeeth (Deemed to be University), Puducherry, India

Corresponding Author: Geetha C, Child Health Nursing, Kasturba Gandhi Nursing College, Sri Balaji Vidyapeeth (Deemed to be University), Puducherry, India, Phone: +91 8807788796, e-mail: geethakasii@ gmail.com

How to cite this article: Geetha C. Effectiveness of Information, Education, Communication Package on Knowledge Regarding Prevention of Road Traffic Accidents among High School Students in a Selected School at Puducherry. Pon J Nurs 2021;14(3):53-55.

Source of support: Nil

Conflict of interest: None

likewise same. In Cuddalore, however, it was discovered that twowheelers and bicycles were frequently committed in accidents. ${ }^{5}$

\section{Need for the Study}

According to the WHO, developing nations account for $80 \%$ of all road accident deaths, with Asia-Pacific accounting for roughly half of all deaths. India is responsible for around $10 \%$ of all traffic

(c) The Author(s). 2021 Open Access This article is distributed under the terms of the Creative Commons Attribution 4.0 International License (https://creativecommons. org/licenses/by-nc/4.0/), which permits unrestricted use, distribution, and non-commercial reproduction in any medium, provided you give appropriate credit to the original author(s) and the source, provide a link to the Creative Commons license, and indicate if changes were made. The Creative Commons Public Domain Dedication waiver (http://creativecommons.org/publicdomain/zero/1.0/) applies to the data made available in this article, unless otherwise stated. 
accidents worldwide. Every year, an estimated 1,275,000 people are seriously injured on the road. ${ }^{9}$ In the previous year, the prevalence of all unintentional injuries among all groups in Cuddalore district was $30.6 \%$. Enhancing road safety is a difficult undertaking, for which we must all take responsibility if we are to succeed. ${ }^{5}$

Bini Paul et al. (2014) conducted a quasi-experimental study in specified Chennai schools to examine children's understanding of road traffic accidents (RTAs). In a pretest of 100 samples, it was found that $83 \%$ had insufficient knowledge of road traffic norms and regulations, while $17 \%$ had somewhat adequate knowledge. The posttest findings showed that $99 \%$ of the children had appropriate understanding and $1 \%$ had moderate knowledge about RTAs after the organized instruction program. The proposed teaching program was successful in boosting awareness of RTA prevention among school-aged children, with implications for nurses, the community, and teachers. ${ }^{6}$

According to a report by the Puducherry traffic police, there were around 1,051 booked accident cases in Puducherry in 2014, with 142 persons losing their lives and 927 persons suffering mildto-serious injuries. ${ }^{11}$ As a result, the current research focuses on school children's understanding of numerous risk factors related to roadside accidents and their practices. As a result, the researchers believe that there is a need to improve high school students' awareness of RTA prevention, so that they can observe traffic regulations among themselves and their peer groups. ${ }^{11}$

\section{Problem Statement}

A study to assess the effectiveness of information, education, communication (IEC) package on knowledge regarding prevention of RTAs among high school students in selected school at Puducherry.

\section{Objectives}

- To assess the knowledge regarding prevention of RTAs among high school students in selected school at Puducherry.

- To assess the effectiveness of IEC package on knowledge regarding prevention of RTAs among high school students in selected school at Puducherry.

- To find out the association between knowledge scores with selected demographic variables.

\section{Hypotheses}

$\mathrm{H}_{1}$ - There is a significant difference in the pretest and posttest levels of knowledge on prevention of RTA among high school students.

$\mathrm{H}_{2}$ - There is a significant association between the knowledge regarding prevention of RTA with selected demographic variable.

The conceptual framework was based on Bertalanffy System's Model, which was published in 1998. In this study, the above theory was used.

\section{Methods and Materials}

Preexperimental one-group pretest-posttest design was adapted for this study. Based on inclusion and exclusion criteria, a simple random sampling technique was employed to pick a sample of 50 high school students from Dr BR Ambedhkar Government Higher Secondary School, Kirumampakkam, Puducherry.

There are two parts to this questionnaire. Part I: demographic and socioeconomic data. Part II: information on how to avoid a RTA. It comprises 50 questions about RTA prevention. The student's replies were used to determine the score. Each correct response receives one point, while incorrect answers receive zero points: 75-100\%—adequate knowledge, 50-75\% — moderately adequate knowledge, and $50 \%$-inadequate knowledge. The instrument was validated, and the content validity was established based on the experts' recommendations.

A pilot study was done to evaluate the efficiency of an IEC package on high school students' understanding of RTA prevention in Puducherry. Permission was received from the institution's head before beginning data collection.

The sample was chosen using a random selection procedure and 50 high school students who matched the inclusion criteria. The information from the students was gathered through an interview using a structured questionnaire. The data were examined using descriptive and inferential statistics, percentage distribution for demographic factors, and high school student knowledge of RTA prevention. They were evaluated for utilizing the IEC package on RTA prevention. Both descriptive statistics and inferential statistics were used to analyze the data.

\section{Results \\ Major Findings}

According to the findings of the study, 36 (72\%) of 50 high school students had appropriate knowledge, 14 (28\%) had moderate knowledge, and $0(0 \%)$ had insufficient information about the prevention of RTAs. The posttest findings revealed that $36(72 \%)$ of them had adequate knowledge and 14 (28\%) had moderate knowledge on RTAs.

Table 1 states the pretest knowledge among high school students: 34 (68\%) of them had inadequate knowledge, $16(32 \%)$ of them had moderate knowledge, and $0(0 \%)$ of them had adequate knowledge. In posttest knowledge among high school students, $36(72 \%)$ of them had adequate knowledge, $14(28 \%)$ of them had moderate knowledge, and $0(0 \%)$ of them had inadequate knowledge.

Table 2 shows the pretest and posttest $p$-values on prevention of RTA $<0.001^{*}$. In posttest knowledge among high school students, $36(72 \%)$ of them had adequate knowledge, 14 (28\%) of them had moderateknowledge, and $0(0 \%)$ of them had inadequate knowledge.

Table 1: Percentage distribution of pretest and posttest levels of knowledge regarding prevention of RTA among high school students

\begin{tabular}{lcccc}
\hline & \multicolumn{4}{c}{$N=50$} \\
\cline { 2 - 5 } Level of & \multicolumn{2}{c}{ Pretest } & \multicolumn{2}{c}{ Posttest } \\
\cline { 2 - 5 } knowledge & Frequency & Percentage & Frequency & Percentage \\
$(\%)$ & 0 & $(n)$ & $(\%)$ \\
\hline Adequate & 16 & 32 & 14 & 72 \\
Moderate & 34 & 68 & 0 & 28 \\
Inadequate & 50 & 100 & 50 & 0 \\
Total & & & & 100 \\
\hline
\end{tabular}

Table 2: Mean, standard deviation, and " $t$ " value of knowledge regarding prevention of RTA among high school students

\begin{tabular}{|c|c|c|c|c|c|c|}
\hline $\begin{array}{l}\text { Knowledge } \\
\text { score }\end{array}$ & Mean & $\begin{array}{c}\text { Std. } \\
\text { deviation }\end{array}$ & $\begin{array}{l}\text { Std. } \\
\text { error }\end{array}$ & $\begin{array}{c}\text { Difference } \\
\text { in means }\end{array}$ & $t$-test & $p$-value \\
\hline Pretest & 13.58 & 2.921 & 0.413 & \multirow{2}{*}{-10.88} & \multirow{2}{*}{-16.547} & \multirow{2}{*}{$<0.001^{*}$} \\
\hline Posttest & 24.46 & 2.957 & 0.418 & & & \\
\hline
\end{tabular}


There was no association between the levels of knowledge regarding prevention of RTA with selected demographic variables. But, the mode of transport is nearly associated with knowledge level, and the $p$-value is 0.975 . Thus, the research hypothesis $\mathrm{H}_{2}$ was rejected.

\section{Discussion}

Major findings of the study were discussed as follows:

The first objective was to assess the knowledge regarding prevention of RTA among high school students at Dr BR Ambedhkar Government Higher Secondary School. The pretest findings revealed that 50 samples had adequate knowledge, 16 (32\%) samples had intermediate knowledge, and 34 (68\%) samples had inadequate knowledge.

The second objective was to evaluate the effect of IEC package on knowledge regarding prevention of RTA among high school students. After administering a posttest to the selected 50 samples, 36 (72\%) of them had adequate knowledge, 14 (28\%) had moderate knowledge, and $0(0 \%)$ had inadequate knowledge.

The third objective was to find out the associate level of knowledge regarding prevention of RTA with selected demographic variables. There is no association between the level of knowledge on RTA prevention and certain demographic characteristics. However, the method of transportation is nearly related to knowledge level, with a $p$-value of 0.975 . As a result, the research hypothesis was rejected.

\section{Recommendation}

- A study can be done to assess the knowledge on prevention of RTA among drivers.

- The study can be conducted on a large population to obtain a more generalized concept regarding understanding of RTA prevention.

\section{Conclusion}

According to the findings of the study, the IEC package on RTAs was efficient in raising knowledge of traffic regulations and lowering the number of RTAs among high school students.

\section{References}

1. Garg N, Hyder AA. Road traffic injuries in India. Scand J Public Health 2006;34(1):100-109. DOI: 10.1080/14034940510032149.

2. Banti P, Koivala B, Rauniyar A, Chaudhary D, Kharel T, Khadka SB. An epidemiological study of road traffic accident cases attending emergency department of teaching hospital. JNMA Apr-Jun 2006;45(162):238-243. PMID: 17189968.

3. Rathinam C. Self-reported motorcycle riding behavior among school children in India. Accid Anal Prev 2007;39(2):334-339. DOI: 10.1016/j. aap.2006.09.002.

4. Chandra Shekar BR, Reddy CVK. A five year retrospective statistical analysis of maxillofacial injuries. Indian J Dent Res 2008;19(4):304-308. DOI: $10.4103 / 0970-9290.44532$.

5. Jaung MS, Yu S, Stallones $L$, Xiang $H$. Road traffic injuries among middle school students. The research Institute at nationwide children's hospital, USA. Traffic Inj Prev 2009;10(3):243-251. DOI: 10.1080/15389580902775147.

6. Dandona R, Mishra A. Deaths due to road traffic crashed in Hyderabad city in India. Natl Med J India 2004;17(2):74-79. PMID: 15141599.

7. Available from: http://jpubhealth.oxfordjournals.org/cgi/ reprint/20/2/139.pdf.

8. Organization for Economic Co-operation and Development. Keeping children safe in traffic. OECD; 2004.

9. Salamon J, Salmon L, Crawford DA, Hume C, Timperio A. Individual, social, and environmental barriers and children's walking or cycling to school. Am J Health Promot 2007;22(2):107-113. DOI: 10.4278/0890 1171-22.2.107.

10. Schnfer I, Barkmann C, Reideser P, Schulte-Markwort M. Posttraumatic syndromes in children and adolescents after road traffic accidents. J Psychopathol 2006;39(4):159-164. DOI: 10.1159/000092676.

11. Available from: http://www.transport.qld.gov.au/Home/Safety/ Road/. 